Jurnal Geografi, Edukasi dan Lingkungan (JGEL) Vol. 5, No. 1, Januari 2021:46-51

P-ISSN: 2579-8499; E-ISSN: 2579-8510

Doi: https://doi.org/10.22236/jgel.v5i1.5424

Website: http://journal.uhamka.ac.id/index.php/jgel

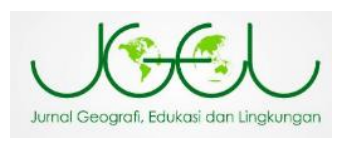

\title{
Pengaruh Kepadatan Penduduk Terhadap Jumlah Kasus Mingguan Covid-19 Di Kabupaten Badung Provinsi Bali
}

\author{
Dwi Novia Wahyuni* \\ Program Studi Pendidikan Geografi, Jurusan Geografi, Fakultas Hukum dan Ilmu Sosial, \\ Universitas Pendidikan Ganesha, Bali, Indonesia \\ *Email: dwinoviawahyuni14@gmail.com \\ Received: 21082020 / Accepted: 1801 2021/ Published online: 29012021
}

\begin{abstract}
ABSTRAK
Geografi mengkaji fenomena di Bumi dengan menganalisis ragam dinamika termasuk pada unsur sosial lingkungan, seperti terjadinya sebaran pandemi Covid-19 di Kabupaten Badung Provinsi Bali dengan pendekatan spasial. Adapun tujuan dalam penelitian ini ialah mengetahui hubungan antara variabel kepadatan penduduk di Kabupaten Badung dengan kasus COVID-19 dan memetakan tingkat kejadian mingguan COVID-19. Dalam melihat analisis pengaruh antar variabel digunakan metode analisis korelasi dan regresi, sedangkan dalam memetakan serta menganalisis tingkat kejadian menggunakan software ArcGIS. Hasil dari penelitian ini adalah terdapat hubungan sangat lemah antar variabel sebesar 1,7\%, dikarenakan kejadian COVID-19 di Kabupaten Badung hanya meningkat pada kecamatan yang memiliki kepadatan penduduk sedang sehingga variabel kepadatan penduduk bukanlah penyebab utama dan tidak berpengaruh secara signifikan terhadap penyebaran COVID-19. Selain itu, temuan dari hasil interpretasi peta menunjukkan terdapat beberapa kecamatan yang tetap konstan pada tingkat kejadian rendah yang disebabkan oleh kepatuhan masyarakat dalam menerapkan kebijakan pemerintah setempat.
\end{abstract}

Kata Kunci: Kepadatan Penduduk, COVID-19, Peta Tingkat Kejadian

\section{ABSTRACT}

The geography is analysis phenomenon of the Earth with several dynamic event also the social environmental like the pandemic Covid-19 efect in Badung District Bali by Spatial perspective. The aims of this reseacrh is to determine the relationship between population density variables in Badung Regency and the COVID-19 cases and to map the weekly incidence rate of COVID-19. In looking at the analysis of the influence between variables, correlation and regression analysis methods are used, while in mapping and analyzing the level of incidence using ArcGIS software. The result of this study is that there is a very weak relationship between variables of $1.7 \%$, because the incidence of COVID19 in Badung Regency only increases in sub-districts that have moderate population density so that the population density variable is not the main cause and does not really affect the spread of COVID-19. In addition, the findings from the map interpretation results show that there are several sub-district that remain constant at a low incidence rate due to community compliance in implementing local government policies.

Keywords : Population density, COVID-19, Case Rate Maps 


\section{PENDAHULUAN}

Geografi pada hakekatnya merupakan bidang atau disiplin ilmu yang mempelajari gejala-gejala di permukaan bumi yang memiliki kompleksitas dan selalu berubah (Citra \& Sarmita, 2016). Penjelasan tersebut menegaskan bahwa geografi mengkaji fenomena geosfer yaitu peristiwa yang terjadi di permukaan bumi, dengan menggunakan pendekatan khas geografi yang tidak dimiliki ilmu lain yaitu pendekatan keruangan, kelingkungan dan kompleks wilayah. Dalam melakukan analisis terhadap fenomena geosfer, penggunaan ketiga pendekatan tersebut disesuaikan dengan topic atau tema kajian (Aksa et al., 2019), seperti bencana pandemi virus yang sedang melanda dunia saat ini dapat dikaji menggunakan pendekatan keruangan dengan menekankan pada kajian sebaran kasus antar wilayah dengan lainnya.

Menurut UU No. 24 Tahun 2007, bencana adalah peristiwa yang mengancam kehidupan dan penghidupan masyarakat, baik disebabkan oleh faktor alam, non alam maupun manusia yang mengakibatkan timbulnya korban jiwa, kerusakan dan kerugian. Salah satu bencana non alam yang dapat mengancam dan mengganggu keberlangsungan kehidupan masyarakat yaitu pandemi COVID-19 (Corona Virus Disease 2019).

Pasien COVID-19 terinfeksi oleh virus jenis betacoronavirus tipe baru yang diberi nama Severe acute respiratory syndrome coronavirus-2 (SARS-Cov-2) (WHO, 2020). Kebanyakan virus ini menginfeksi hewan dan bersikulasi di hewan liar, virus ini disebut dengan virus zoonotik karena mampu bertransmisi dari hewan ke manusia (Yuliana, 2020). Akan tetapi, hingga saat ini kasus penyebaran akumulatif di indonesia mengalami peningkatan secara agresif. Hal ini dikarenakan SARS-Cov-2 mampu menyebar melalui manusia ke manusia (Munster et al., 2020) melalui droplet yang keluar dari seseorang yang terinfeksi. Virus ini meyerang sistem pernafasan manusia dengan gejala yang muncul setelah masa inkubasi. Semenjak kasus pertama kali dilaporkan di Wuhan akhir 2019 lalu virus ini telah menyebar di banyak negara dalam waktu yang singkat, sehingga
WHO menyatakan virus ini sebagai pandemi dunia (Cirjak, 2020).

Meningkatnya jumlah penduduk akibat aktivitas ekonomi yang terus berkembang mendorong bertambahnya daerah permukiman dan menyebabkan naiknya tingkat kepadatan penduduk (Yusrina et al., 2018). Kepadatan penduduk memiliki andil dalam penyebaran COVID-19 di Indonesia, hal ini merujuk pada kenyataan bahwa kawasan perkotaan yang memiliki tingkat kepadatan penduduk tinggi dibandingkan daerah pinggiran akan menyebabkan transmisi penyakit lebih cepat dengan rantai penyebaran yang lebih kompak dan kompleks (Hardianto, 2020). Parameter ini terbukti mempengaruhi penyebaran COVID-19 di Negara Bagian India Selatan berdasarkan penelitian yang dilakukan oleh Arif \& Sengupta (2020), terdapat tiga negara bagian yang memiliki tingkat kepadatan tinggi dan memiliki penyebaran kasus yang tinggi yaitu Tamil Nadu, Karnataka dan Telangana. Selain itu terdapat temuan lain yang menyatakan adanya korelasi antara kepadatan penduduk dan wabah penyakit dalam penelitian Li et all (2018) dalam (Hardianto, 2020). Namun penelitian yang dilakukan di Amerika oleh (Hamidi et al., 2020), setelah mengontrol kondisi social ekonomi dan infrastruktur pelayanan kesehatan di kota metropolitan negara bagian Amerika, menemukan bahwa tidak ada hubungan korelasi antara kepadatan penduduk dengan penyebaran COVID-19 dan angka kematian rendah di wilayah dengan kepadatan tinggi sedangkan pada wilayah dengan kepadatan penduduk yang rendah angka kematian tinggi.

Berdasakan data Gugus Tugas Percepatan dan Penanganan COVID-19, Provinsi Bali merupakan wilayah dengan tingkat penyebaran dan kematian yang rendah jika dibandingkan dengan Provinsi yang ada di Pulau Jawa (Tabel 1). Hal itu menarik untuk dilakukan kajian mengingat Kabupaten Badung menjadi destinasi wisata yang mendatangkan ribuan wisatawan asing tiap bulannya, khususnya memetakan tingkat kejadian COVID-19. Sehingga tujuan dari penelitian ini adalah mengetahui hubungan antara variabel kepadatan penduduk di Kabupaten Badung dengan kasus COVID-19 dan memetakan tingkat kejadian mingguan 
COVID-19 berdasarkan variabel yang digunakan.

Tabel 1. Perbandingan data Kasus Covid-19 pada tingkat Provinsi.

\begin{tabular}{|c|c|c|c|c|c|c|}
\hline \multirow{2}{*}{ Provinsi } & \multicolumn{2}{|c|}{ Positif } & \multicolumn{2}{c|}{ Sembuh } & \multicolumn{2}{c|}{ Meninggal } \\
\cline { 2 - 7 } & Jumlah & $\begin{array}{c}\text { Ratagn } \\
\text { Penambahan } \\
\text { Per Hari }\end{array}$ & Jumlah & $\%$ & Jumlah & $\%$ \\
\hline $\begin{array}{c}\text { DKI } \\
\text { Jakarta }\end{array}$ & 229,726 & 784 & 204,471 & 89.01 & 3,774 & 1.64 \\
\hline $\begin{array}{c}\text { Jawa } \\
\text { Barat }\end{array}$ & 114,072 & 408 & 92,664 & 81.23 & 1,375 & 1.21 \\
\hline $\begin{array}{c}\text { Jawa } \\
\text { Tengah }\end{array}$ & 104,463 & 373 & 69,047 & 66.10 & 4,568 & 4.37 \\
\hline $\begin{array}{c}\text { Jawa } \\
\text { Timur }\end{array}$ & 100,225 & 336 & 85,737 & 85.54 & 6,968 & 6.95 \\
\hline $\begin{array}{c}\text { Sulawesi } \\
\text { Selatan }\end{array}$ & 41,697 & 145 & 36,051 & 86.46 & 693 & 1.66 \\
\hline $\begin{array}{c}\text { Kalimant } \\
\text { an Timur }\end{array}$ & 33,966 & 119 & 27,526 & 81.04 & 881 & 2.59 \\
\hline Riaul & 27,459 & 96 & 25,315 & 92.19 & 642 & 2.34 \\
\hline $\begin{array}{c}\text { Sumatera } \\
\text { Barat }\end{array}$ & 25,635 & 88 & 22,044 & 85.99 & 569 & 2.22 \\
\hline Banten & 22,355 & 78 & 11,618 & 51.97 & 497 & 2.22 \\
\hline Bali & 21,929 & 74 & 18,933 & 86.34 & 601 & 2.74 \\
\hline
\end{tabular}

Sumber: infocorona.baliprov.go.id

\section{METODE PENELITIAN}

Objek dalam penelitian ini adalah kepadatan penduduk dan tingkat kejadian Covid 19 di Kabupaten Badung, dengan menggunakan sampel kecamatan yang berjumlah 6 Kecamatan. Terkait lokasi penelitian dapat dilihat pada Gambar 1.

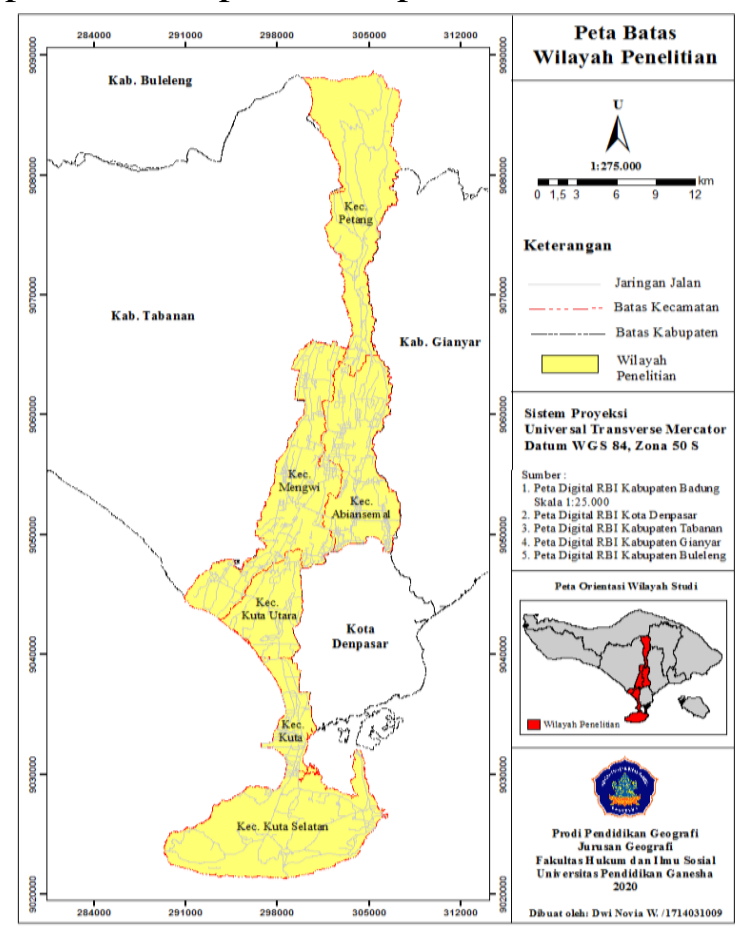

Gambar 1. Peta Batas Wilayah Penelitian
Adapun data yang digunakan adalah data kepadatan penduduk diperoleh dari data BPS 2018 dan data harian kasus COVID-19 bersumber dari kanal resmi GTPP COVID-19 Kabupaten Badung. Sedangkan dalam memetakan tingkat kejadian COVID-19 memerlukan data digital administrasi wilayah yang didapat dari kanal Badan Informasi Geospasial (BIG). Teknik analisis data yang digunakan untuk melihat hubungan dan pengaruh adalah analisis korelasi dan regresi linier. Sedangkan untuk memetakan tingkat kejadian COVID-19 dengan bantuan software ArcGIS.

\section{HASIL DAN PEMBAHASAN}

Hubungan Variabel Kepadatan Penduduk Dengan Kasus Mingguan COVID-19 Di Kabupaten Badung

Data kepadatan penduduk menurut kecamatan di Kabupaten Badung dan kasus COVID-19 per-minggu (20 Mei - 26 Juni 2020) dapat dilihat pada Tabel 2.

Tabel 2. Kepadatan Penduduk dan Kasus Mingguan COVID-19

\begin{tabular}{|c|c|c|c|c|c|c|}
\hline \multirow{2}{*}{$\begin{array}{l}\text { Kecamat } \\
\text { an }\end{array}$} & \multirow{2}{*}{$\begin{array}{l}\text { Kepa } \\
\text { datan }\end{array}$} & \multicolumn{5}{|c|}{ Kasus Mingguan } \\
\hline & & $\begin{array}{l}20- \\
27 \\
\text { mei }\end{array}$ & $\begin{array}{l}28- \\
03 \\
\text { juni }\end{array}$ & $\begin{array}{l}04- \\
10 \\
\text { juni }\end{array}$ & $\begin{array}{l}\text { 11- } \\
17 \\
\text { juni }\end{array}$ & $\begin{array}{l}18- \\
26 \\
\text { juni }\end{array}$ \\
\hline $\begin{array}{l}\text { Kuta } \\
\text { Selatan }\end{array}$ & 1629 & 11 & 14 & 19 & 24 & 30 \\
\hline Kuta & 6145 & 0 & 0 & 2 & 4 & 6 \\
\hline $\begin{array}{l}\text { Kuta } \\
\text { Utara }\end{array}$ & 3979 & 6 & 11 & 19 & 30 & 48 \\
\hline Mengwi & 1609 & 13 & 23 & 26 & 28 & 33 \\
\hline $\begin{array}{l}\text { Abianse } \\
\text { mal }\end{array}$ & 1334 & 2 & 6 & 14 & 19 & 50 \\
\hline Petang & 224 & 1 & 1 & 2 & 2 & 5 \\
\hline
\end{tabular}

Sumber: Badan Pusat Statistik, 2019 dan GTPP COVID-19 BALI, 2020

Hubungan kedua variabel menunjukkan arah yang berlawanan, dimana variabel nilai kepadatan penduduk semakin tinggi maka variabel kasus COVID-19 semakin menurun. Hasil dari analisis regresi linear juga menunjukkan hubungan pengaruh yang lemah diantara kedua variabel dengan nilai R Square sebesar 0,017 yang berarti bahwa besaran pengaruh kepadatan penduduk sebesar $1,7 \%$ sedangkan sisanya dipengaruhi oleh faktor lain. 
Berdasarkan hasil analisis yang telah dilakukan peningkatan COVID-19 tidak selaras dengan kepadatan penduduk di Kabupaten Badung. Dimana Kecamatan Kuta yang memiliki tingkat kepadatan tertinggi di Kabupaten Badung mengalami tingkat kenaikan kasus yang tidak terlalu signifikan bahkan kasus positif pada kecamatan tersebut tergolong sedikit yaitu sebanyak 6 kasus. Sementara tiga kecamatan lainnya yang memiliki kepadatan 1.000 hingga 3.000 penduduk $/ \mathrm{km}^{2}$ mengalami peningkatan kasus yang signifikan yaitu Kecamatan Kuta Utara, Mengwi dan Abiansemal. Korelasi yang lemah ini disebabkan oleh kasus penyebaran COVID-19 hanya meningkat pada kecamatan yang memiliki kepadatan penduduk sedang sehingga variabel kepadatan penduduk bukanlah penyebab utama dan tidak terlalu berpengaruh terhadap penyebaran COVID-19.

\section{Pemetaan Tingkat Kejadian Mingguan COVID-19}

Pemetaan tingkat kejadian COVID-19 per-kecamatan di Kabupaten Badung dapat memberikan informasi kondisi penyebaran kasus kejadian per-minggu dengan menggunakan range tingkat kejadian sesuai dengan Tabel 3, range kejadian didasarkan pada jumlah kasus positif COVID-19 tiap kecamatan.

Tabel 3. Range Tingkat Kejadian COVID-19

\begin{tabular}{ccc}
\hline $\begin{array}{c}\text { Minggu } \\
\text { ke- }\end{array}$ & Tingkat kejadian & Range kasus \\
\hline \multirow{2}{*}{1} & Tinggi & $11-13$ \\
\cline { 2 - 3 } & Sedang & $2-6$ \\
\cline { 2 - 3 } 2 & Rendah & $0-1$ \\
\cline { 2 - 3 } & Tinggi & $14-23$ \\
\cline { 2 - 3 } & Sedang & $6-11$ \\
\hline \multirow{2}{*}{3} & Rendah & $0-1$ \\
\cline { 2 - 3 } & Tinggi & $19-26$ \\
\hline \multirow{2}{*}{4} & Sedang & 14 \\
\cline { 2 - 3 } & Rendah & 2 \\
\cline { 2 - 3 } & Tinggi & $28-30$ \\
\hline \multirow{2}{*}{5} & Sedang & $19-24$ \\
\cline { 2 - 3 } & Rendah & $2-4$ \\
\cline { 2 - 3 } & Tinggi & $48-50$ \\
\cline { 2 - 3 } & Sedang & $30-33$ \\
\hline & Rendah & $5-6$ \\
\hline
\end{tabular}

Analisis spasial kejadian Covid 19 mingguan di tingkat Kecamatan di sajikan pada Gambar 2. Berdasarkan peta peta tingkat kejadian menunjukkan bahwa Kecamatan Mengwi kodisi penyebarannya tetap konstan dalam tingkat yang tinggi selama 4 minggu. Meskipun pada 18-26 Juni mengalami penurunan menjadi pola spasial sedang. Kasus penyebaran pada kecamatan ini dilatar belakangi oleh Pekerja Migran Indonesia (PMI) yang menularkan kepada keluarganya. Pada Kecamatan Abiansemal memiliki pola spasial cendrung meningkat. Hal ini dapat di di identifikasi pada minggu pertama merupakan area kategori rendah, minggu kedua hingga ke empat mengalami peningkatan menjadi area persebaran sedang, dan pada minggu kelima menjadi tingkat kejadian tinggi. Lonjakan kasus pada kecamatan ini diakibatkan oleh transmisi lokal dari pekerja Denpasar yang merupakan warga asli Abiansemal.

Kecamatan Kuta Utara mengalami peningkatan penyebaran pada minggu keempat dan kelima menjadi tingkat kejadian tinggi. Padahal pada minggu sebelumnya merupakan area dengan kategori sedang. Berbeda dengan Kecamatan Kuta Selatan pada minggu pertama hingga minggu kelima cendrung konsisten, dengan pola sepasial sebagai kategori penyebaran Covid 19 dengan kategori sedang. Kondisi ini disebabkan oleh aksi tanggap darurat antar masyarakat dengan Pemerintah Desa yang memberlakukan jam malam dan menjaga portal keluar masuk perumahan di Kecamatan Kuta Selatan. Tingkat penyebaran rendah tetap terjadi di Kecamatan Petang dan Kuta selama lima minggu berturut-turut, kasus peningkatan pada kedua kecamatan ini tidak bertambah secara signifikan. Selain itu, kedua Kecamatan tersebut merupakan area dengan kategori rendah. Kondisi ini dapat di identifikasi area tersebut merupakan padat penduduk dikarenakan factor wisatawan, adanya kondisi pembatasan kegiatan turis berdampak pada berkurangnya aktivitas pada wilayah tersebut. 

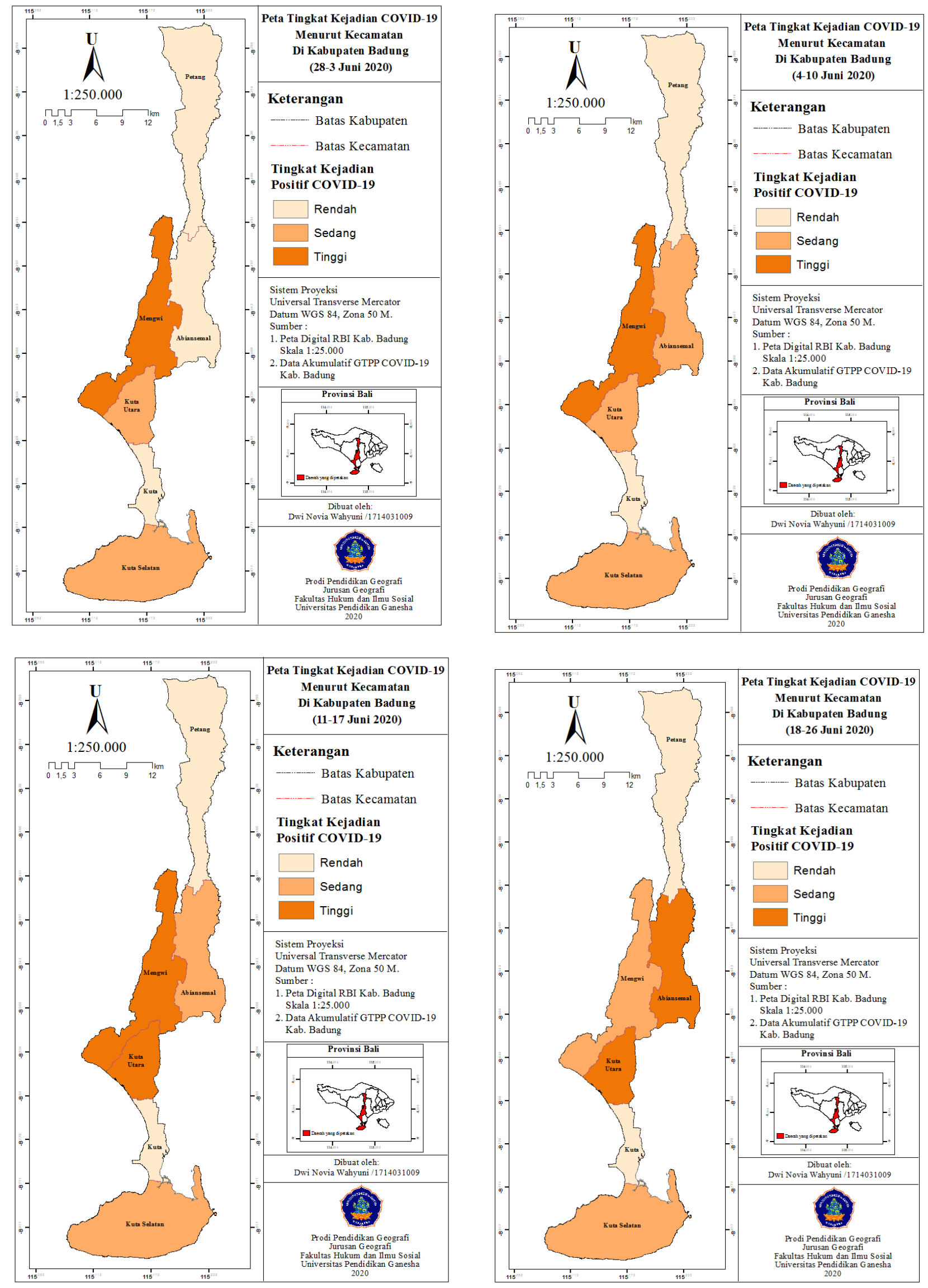

Gambar 2. Peta Tingkat Kejadian COVID-19 Mingguan 


\section{KESIMPULAN}

Berdasarkan penelitian yang telah dilakukan, dapat ditarik kesimpulan sebagai yaitu: Hasil dari analisis korelasi dan regresi linier bahwa parameter kepadatan penduduk korelasinya sangat lemah terhadap kasus COVID-19 di Kabupaten Badung. Besaran pengaruh variabel kepadatan penduduk sebesar 1,7\%, dikarenakan oleh kasus penyebaran COVID-19 di Kabupaten Badung hanya meningkat pada kecamatan yang memiliki kepadatan penduduk sedang sehingga variabel kepadatan penduduk bukanlah penyebab utama dan tidak terlalu berpengaruh terhadap penyebaran COVID-19.

Hasil interpretasi peta tingkat kejadian per-minggu di Kabupaten Badung menunjukkan terdapat kecamatan yang tetap konstan pada tingkat kejadian rendah yaitu Kecamatan Petang dan Kecamatan Kuta, sedangkan Kecamatan Abiansemal mengalami perubahan dari tingkat kejadian sedang menjadi tinggi pada minggu kelima, penyebabnya adalah transmisi lokal dari Pedagang yang merupakan warga Kecamatan Abiasemal yang berdagang di Pasar Kumbasari Denpasar sehingga menularkan pada keluarganya.

\section{DAFTAR PUSTAKA}

Aksa, F. I., Utaya, S., \& Bachri, S. (2019). Geografi dalam Perspektif Filsafat Ilmu. Majalah Geografi Indonesia, 33(1), 4347.

Arif, M., \& Sengupta, S. (2020). Nexus between population density and COVID19 pandemic in the south Indian State: A geo-statistical approach (pp. 1-22). Department of Geography, Visva-Bharati (A Central University).

Badan PusatStatistik. (2019). Kabupaten Badung Dalam Angka 2019.

Cirjak, A. (2020). How Coronavirus Has Helped The Planet. Worldatlas. https://www.worldatlas.com/articles/how -coronavirus-has-helped-the-planet.html

Citra, I. P. A., \& Sarmita, I. M. (2016). Identifikasi Potensi Wilayah Desa Sangsit Sebagai Laboratorium Lapangan Geografi Untuk Menunjang Mata Kuliah Kerja Lapangan. Jurnal Media
Komunikasi Geografi, 17(2), 76-87.

GTPPCOVID-19 BALI. (2020). Provinsi Bali

Tanggap

COVID-19.

https://infocorona.baliprov.go.id/

Hamidi, S., Sabouri, S., \& Ewig, R. (2020). Does Density Aggravate the COVID-19 Pandemic? Jornal of the American Planning Association, O(0), 1-15.

Hardianto, J. (2020). Korelasi Kepadatan Penduduk dan Penyebaran COVID-19. Rujak Center For Urban Studies.

Munster, V. J., Koopmans, M., Doremalen, N. van, Riel, D. van, \& Wit, E. de. (2020). A Novel Coronavirus Emerging in ChinaKey Question For Impact Assessment. The New England Journal of Medicine, 382(8), 692-694.

Presiden Replubik Indonesia. (2007). UndangUndang Replubik Indonesia Nomor 24 Tahun 2007 Tentang Penanggulangan Bencana.

WHO. (2020). WHO Director-General's remark at the media briefing on 2019nCov on 11 February 2020. World Health Organization (WHO).

Yuliana. (2020). Corona virus diseases (Covid-19); Sebuah tinjauan literatur. Wellness and Healthy Magazine, 2(1), 187-192.

Yusrina, farida N., Sari, M. I., Pratiwi, G. C. A. H., Hidayat, D. W., Jordan, E., \& Febriyanti, D. (2018). Analisis Pola Permukiman Menggunakan Pendekatan Nearest Neighbour Untuk Kajian Manfaat Objek Wisata Di Kecamatan Prambanan Kabupaten Klaten. Jurnal Geografi, Edukasi Dan Lingkungan (JGEL), 2(2), 110-120. 